\title{
Effects of Extraction Solvents on the Yield and Physicochemical Properties of Mangifera indica L. Seed Oil \\ NWAOKOBIA, IDIBIE, OGBORUR and OKOLIE
}

\begin{abstract}
The extraction of oil from mango seeds was investigated using a Soxhlet Extractor. Mango seeds were collected, dried and grounded into powder. Hexane and ethanol were used to extract the oil at varying time of extraction of 4, 5, 6, 7 and 8 hours, respectively. Result shows that yield is time dependent, as increase in time of extraction results into increase in yieldwhere the least time of $4 \mathrm{hrs}$ yielded an average of $4.00 \%$ and $8 \mathrm{hrs}$ yielded an average of $13.06 \%$ for hexane. While the use of ethanol at $4 \mathrm{hr}$ and $8 \mathrm{hrs}$ only yielded $1.99 \%$ and $8.22 \%$.Thus the use of hexane achieved the maximum yield (13.06\%) of oil extracted. The effects of time and extraction solvent on the yield of oil was investigated by using a $2^{2}$ factorial design and, result shows that factor ' $A$ ' which is time, produces the greatest effect (7.665) in the yield of mango than factors ' $\mathrm{B}$ ' (3.335) being solvent and 'AB'(1.335) being interaction between solvent and time. The effect of the extraction solvent on the physicochemical properties was also investigated where theoil extracted with hexane was found to possess better overall quality than the ethanol extracts, asits acid value, saponification value, ester value, refractive index and specific gravity were $5.61 \mathrm{mgKOH} / \mathrm{gOil}, 207 \mathrm{mgKOH} / \mathrm{gOil}, 201.39 \mathrm{mgKOH} / \mathrm{gOil}, 1.443$ and 0.909 , respectively as against $30.30 \mathrm{mgKOH} / \mathrm{gOil}, 205 \mathrm{mgKOH} / \mathrm{gOil}, 174.70 \mathrm{mgKOH} / \mathrm{gOil}$ and 0.909 , respectively of ethanol. The results didn't only show that hexane gives a higher yield of oil than ethanol but also revealed that hexane is a much better solvent for the extraction of mango seed oil.
\end{abstract}

Key words: Mangiferaindica, Seed oil, Extraction and Physicochemical Characterization

The mango fruit is a drupe or stone fruit which embeds a shell within its hardened endocarp. MangiferaIndicatree belongs to the Anarcardiaceae family, a family of fruit bearing trees (Singh, 1960). Mangoes are one of the most important fruits worldwide and they are grown in tropical and subtropical regions especially Asia (Fahimdanesh \& Bahrami, 2013). The mango is original to the Indian subcontinent, South-east Asia and Africa. It is cultivated in many tropical regions and distributed widely in the world (Singh, 1960). It is one of the most extensively exploited fruits for food, juice, flavour, fragrance and colour and is a common ingredient in new functional foods. Chutneys, jams, sauce, nectar, pickles are also made from mangoes. Various parts of the tree are used in medicines and its leaves are ritually used as floral decorations at weddings and religious ceremonies (Kittiphoom, 2012 and Bird, 2013).).

Mango trees (MangiferaIndica) reach 35 $40 \mathrm{~m}$ in height, with a crown radius of $10 \mathrm{~m}$. The leaves are evergreen, alternate, simple, $15-35 \mathrm{~cm}$ long and $6-16 \mathrm{~cm}$ broad; when the leaves are young they are orange-pink, rapidly changing to a dark glossy red, and then dark green as they mature. The fruit takes from 3 - 6 months to ripen. The ripe fruit is variable in size and colour, and may be yellow, orange, red or green when ripe, depending on the cultivar (Fahimdanesh \& Bahrami, 2013). Nearly half of the world's mangoes are produced in India, but the country accounts for a small percentage of the international trade because India 
consumes most of its own production(Sondhi, 2011). While India is the largest producer of Mangoes in the world China and Thailand are the second and third largest producers, respectively (Preedyet al, 2011;Kittiphoom, 2012). The fruit pulp is high in dietary fiber, vitamin $\mathrm{C}$ and vitamin A (Nigam, 2007). It contains essential vitamins and dietary minerals at good levels. The mango peel also contains essential nutrients. According to mango varieties, the seed (kernel and endocarp) represents from $10 \%-25 \%$ of the whole fruit weight. The kernel inside the seed represents from $45 \%-75 \%$ of the seed and about $20 \%$ of the whole fruit(Fahimdanesh \& Bahrami, 2013). The kernel can be ground into kernel powder for oil extraction.The oil is semi-solid at room temperatures, but melts on contact with skin, making it appealing for baby creams, heat-care balms, hair products and other moisturizing products(Sivkishen, 2014). Also, the confectionary industry has developed an interest in the possibility of using mango kernel oil as a substitute for Cocoa butter which is very expensive (O'Brien, 2008).

The fruit of the Mango is never totally consumed or processed because the seed is protected by a hardened shell (endocarp). This seed is majorly disposed of after consumption but could also besubjected to industrial processing.(Pomeranz,
2002). Due to the large utilization of mango fruits, more than one million tons of mango seeds are being produced as waste annually(Fahimdanesh \& Bahrami, 2013). If these seeds could be utilized one way or another, it would eliminate wastage and also birth the production of new products. The usefulness of the whole Mango kernel, especially the oil, in comparison with mango juice, is yet to gain rural and industrial attraction in African countries including Nigeria. This underutilization could be partly due to the limited knowledge of the composition of the kernel oil and its toxicology status (Nielsen, 2010) hence, this research work is necessary so as to provide more knowledge on the required experimental conditions for optimum production of mango kernel oil and on the properties of the oil. Therefore, this work is not only aimed at extracting oil from mango seeds by varying experimental conditions and characterizing the oil, but todetermine the effect of solvent extraction on the physiochemical properties of the extracted oil.

\section{MATERIALS AND METHODS}

Raw materials and reagents

Ripe mangoes were obtained from Oba Market, Benin City in Oredo Local Government Area of Edo state, Nigeria, hexane and ethanol were obtained from Charlec Laboratory, Nigeria Ltd.

\section{Methods}

Flowchart of the process is presented in Figure 1

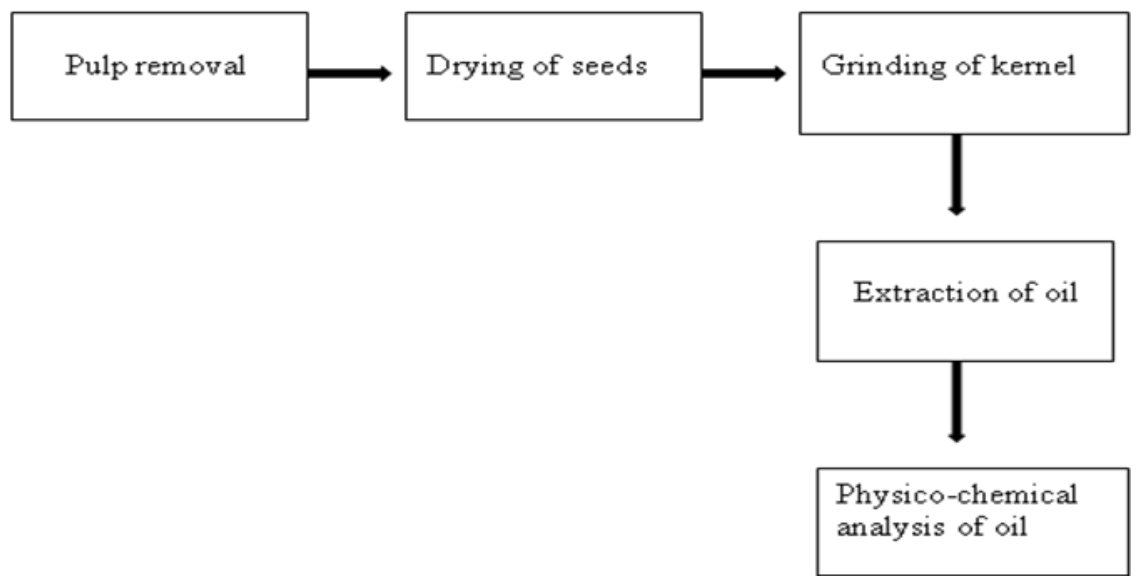


Figure 1: Flowchart process of oil extraction from mango seeds.

Removal of pulp: The mango pulps werepeeled out and the seed kernel were dried gradually.

Drying: The seed kernels were dried in a drying oven at $100^{\circ} \mathrm{C}$ for 8 hours. The seeds were then cracked open and the kernels were removed. However, further drying was carried out on kernels that were still moist.

Grinding: All the kernels were first subjected to preliminary grinding using a mortar and pestle. Then the reduced kernels were further ground using a kitchen blender to make the particle size of the kernel powder less than 2000 microns. The kernel powder was then stored in a plastic container in a cool and dry place.

Extraction of oil: Oil was extracted from the kernel using a soxhlet apparatus and a heating mantle. The soxhlet apparatus is made up of a condenser, an extractor and a flask (round bottom or flat bottom) which is being heated. The kernel powder encapsulated in filter paper was placed in the extractor. The organic solvent used for extraction was placed in the flask. The solvent vaporizes and rises to the condenser where it is condensed. The condensed organic solvent then drips on the kernel powder. The kernel powder upon contact with hot organic solvent begins to secret oil which is soluble in the organic solvent. When the oil and solvent mixture has risen high enough (higher than the siphon tube), the mixture flows through the siphon tube back into the flask. The oil is then recovered from the organic solvent by heating the mixture with a condenser coupled to the flask. The organic solvent vaporizes and is then condensed back into another container.

\section{Effect of time and choice of solvent on oil yield}

Process condition such as time and choice of solvent were carried out to determine their effects on the yield of oil from the kernel powder. The experiment was run 10 times at different times of 4,5,6,7, and 8 hours, respectively using both Hexane and Ethanol as different solvents according to the method described by Willams, (2007).

\section{Physico-chemical analysis of the mango oil} Specific gravity

The specific gravity(SG):This is a dimensionless unit defined as the ratio of density of the mango oil to the density of water at a specified temperature. This was done by measuring the density of mango oil in reference to the density of distilled water at $20^{\circ} \mathrm{C}$ using a specific gravity bottle. First the specific gravity bottle was weighed while empty. It was then filled with mango oil and weighed again. Then the difference in weights was divided by an equal volume of water to obtain the specific gravity of the mango oil.(A.O.A.C, 1998).

\section{Refractive Index}

The refractive index of a substance measures how the substance affects light travelling through it. It is equal to the speed of light in a vacuum divided by the speed of light in that substance. When light travels between two materials with different refractive indexes, it bends at the boundary between them. The refractive index test was carried out using a programmable Refractometer. Here, the apparatus was standardized using pure distilled water whose refractive index at $20^{\circ} \mathrm{C}$ is 1.3330 . This was followed by replacing the distilled water with a drop of the sample in the machine. After about 1-2 minute(s) the machine read off the refractive index.

\section{Saponification Value}

Saponification value is the number of $\mathrm{mg}$ of potassium hydroxide $(\mathrm{KOH})$ required to saponify the esters in $1 \mathrm{~g}$ of a sample, and to neutralize the free acids. It also indicates the amount of average molecular weight of triglycerides contained in the oil. This involves weighing $1 \mathrm{~g}$ of oil into $250 \mathrm{ml}$ dry round bottom flask.50ml of $0.5 \mathrm{ml}$ alcoholic 
potassium hydroxide was added to the oil. Porous beads were added to ensure uniform heating. The reflux condenser was setup and the contents of the round bottom flask was refluxed for about $1 \mathrm{hr}$, after refluxing the mixture is allowed to cool and then titrated against standard hydrochloric acid and the titre values are recorded. Similarly, $50 \mathrm{ml}$ of the same alcoholic $\mathrm{KOH}$, blank (no oil added) was refluxed in a round bottom flask for $1 \mathrm{hr}$, cooled and titrated against standard 0.5N HCL.The titre value was also recorded and the titre value obtained was used to determine the saponification value using Equation (1):

Saponification value $=\frac{56.1 \times Z \times M \text { of } \mathrm{HCl}}{\text { Weight of sample }}$

where: $Z=$ volume of HCL required to neutralize excess alkali $(\mathrm{ml}) ; M=$ strength of the $\mathrm{KOH}$.

Acid value

Acid value (or "neutralization number" or "acid number" or "acidity") is the mass of potassium hydroxide $(\mathrm{KOH})$ in milligrams that is required to neutralize one gram of chemical substance. The acid number is a measure of the amount of carboxylic acid groups in a chemical compound, such as a fatty acid, or in a mixture of other compounds. This involves weighing $1 \mathrm{~g}$ of the oil sample into $250 \mathrm{ml}$ conical flask. Meanwhile 95\% alcohol (neutral alcohol) was prepared by diluting methanol with sodium hydroxide $(5 \mathrm{ml} \mathrm{NaOH}+95 \mathrm{ml}$ ethanol $=$ $100 \mathrm{ml}$ neutral alcohol). $50 \mathrm{ml}$ of neutral alcohol and $50 \mathrm{ml}$ benzene were added to the oil in the flask. The contents of the flask were shaken well to dissolve.The contents were then titrated against $0.1 \mathrm{~N}$ potassium hydroxide solution using phenolphthalein as indicator. The end point was the appearance of a pale permanent pink colour and the titre value were recorded. The acid value is thus calculated using Equation (2):
Acid value $=\frac{X \times M \times 56.1}{\text { Weight of sample }}$

where: $X$ is the volume of $\mathrm{KOH}$ required to neutralize the oil solution; $M$ is the strength of $\mathrm{KOH}$ Ester Value

Ester value was obtained by subtracting the acid value from the saponification value. Ester value represents the number of milligrams of potassium hydroxide required to saponify the esters present in $1 \mathrm{~g}$ of the oil.

\section{RESULTS}

\section{Determination of yield of oil}

For the two extraction solvents, hexane and ethanol, the yield of oil is shown below. (Detailed calculations are shown in appendix C)

Table 1: Yield of oil from hexane extraction

\begin{tabular}{|c|c|c|}
\hline $\begin{array}{c}\text { Time } \\
(\mathrm{hrs})\end{array}$ & $\begin{array}{c}\text { Amount of oil extracted } \\
(\mathrm{g})\end{array}$ & $\begin{array}{c}\text { Average } \\
\text { yield } \\
(\%)\end{array}$ \\
\hline 4 & 1.20 & 4.003 \\
5 & 2.00 & 6.676 \\
6 & 3.00 & 10.021 \\
7 & 3.70 & 12.374 \\
8 & 3.90 & 13.069 \\
\hline
\end{tabular}

Table 2: Yield of oil from ethanol extraction

\begin{tabular}{|c|c|c|}
\hline $\begin{array}{c}\text { Time } \\
(\mathrm{Hrs})\end{array}$ & $\begin{array}{c}\text { Amount of oil extracted } \\
(\mathrm{g})\end{array}$ & $\begin{array}{c}\text { Average } \\
\text { yield } \\
(\%)\end{array}$ \\
\hline 4 & 0.6 & 1.991 \\
5 & 1 & 3.313 \\
6 & 1.7 & 5.629 \\
7 & 2.2 & 7.266 \\
8 & 2.5 & 8.223 \\
\hline
\end{tabular}




\section{Factorial Experiment Design Using Manual Method}

where $\mathrm{A}=$ Time $(-=4$ hours,$+=$ 8hours $) ; \mathrm{B}=$ Organic solvent $(-=$ Hexane,$+=$ Ethanol $)$

Table 3:Manual factorial results (Detailed calculation is shown in appendix C)

\begin{tabular}{|l|l|l|l|l|}
\hline & \multicolumn{2}{|l|}{ Main Effects } & Interaction Effects & \\
\hline Run & A & B & AB & Yield (\%) \\
\hline 1 & - & - & + & 4.00 \\
5 & + & - & - & 13.00 \\
6 & - & + & - & 2.00 \\
10 & + & + & + & 8.33 \\
Absolute value of effect & 7.665 & 3.335 & 1.335 & \\
\hline
\end{tabular}

From the above table, it is shown that factor ' $\mathbf{A}$ ' which is time produces the greatest effect in the yield of mango, 7.665.

Table 4: Factorial Design of Experiment Using Minitab

Minitab Factorial Experiment results

\begin{tabular}{|c|c|c|c|c|c|}
\hline RunOrder & Blocks & CenterPt & Solvent & Time & Yield (\% w/w) \\
\hline 1 & 1 & 1 & Hexane & 4 & 4 \\
2 & 1 & 1 & Hexane & 8 & 13 \\
3 & 1 & 1 & Ethanol & 4 & 2 \\
4 & 1 & 1 & Ethanol & 8 & 8.333 \\
\hline
\end{tabular}

Table 5:Absolute effect of main effects from Minitab

\begin{tabular}{|l|l|}
\hline Term & Absolute effect from Minitab \\
\hline Time (A) & 7.665 \\
Extraction solvent (B) & 3.335 \\
Time and Solvent (AB) & 1.335 \\
\hline
\end{tabular}

Table 6: Physicochemical Properties of extracted mango oil

\begin{tabular}{|l|l|l|l|l|l|}
\hline Oil Sample & $\begin{array}{l}\text { Acid value } \\
\text { (mgKOH/gOil) }\end{array}$ & $\begin{array}{l}\text { Saponification } \\
\text { value(mgKOH/gOil) }\end{array}$ & $\begin{array}{l}\text { Ester } \\
\text { value(mgKOH/gOil) }\end{array}$ & $\begin{array}{l}\text { Refractive } \\
\text { index }\end{array}$ & $\begin{array}{l}\text { Specific } \\
\text { gravity } \\
\text { at 20 } \mathbf{C}\end{array}$ \\
\hline $\begin{array}{l}\text { Extracted with } \\
\text { Hexane }\end{array}$ & 5.61 & 207.0 & 201.39 & 1.443 & 0.909 \\
$\begin{array}{l}\text { Extracted with } \\
\text { Ethanol }\end{array}$ & 30.30 & 205.0 & 174.70 & 1.451 & 0.900 \\
\hline
\end{tabular}


Table 7: Comparison of mango oil yield with literature.

\begin{tabular}{|l|l|l|}
\hline Extraction Solvent (8hours) & $\begin{array}{l}\text { Experiment yield } \\
(\boldsymbol{\%} \mathbf{w} / \mathbf{w})\end{array}$ & $\begin{array}{l}\text { Literature yield } \\
(\boldsymbol{\%} \mathbf{w} / \mathbf{w})\end{array}$ \\
\hline Hexane extract & 13.00 & 13.00 \\
Ethanol extract & 8.33 & 6.96 \\
\hline
\end{tabular}

Table 8:Comparison of Physicochemical properties of extracted oil with literature values

\begin{tabular}{|l|l|l|l|l|l|}
\hline Oil Sample & $\begin{array}{l}\text { Acid value } \\
\text { (mgKOH/gOil) }\end{array}$ & $\begin{array}{l}\text { Saponification } \\
\text { value(mgKOH } \\
\text { /gOil) }\end{array}$ & $\begin{array}{l}\text { Ester value } \\
\text { (mgKOH/gOil) }\end{array}$ & $\begin{array}{l}\text { Refractive } \\
\text { index }\end{array}$ & $\begin{array}{l}\text { Specific } \\
\text { gravity at } \\
\mathbf{2 0} \mathbf{C}\end{array}$ \\
\hline $\begin{array}{l}\text { Hexane } \\
\text { extract } \\
\text { Experimental }\end{array}$ & 5.61 & 207.00 & 201.39 & 1.443 & 0.909 \\
$\begin{array}{l}\text { Hexane } \\
\text { extract } \\
\text { Literature }\end{array}$ & 5.35 & 207.5 & 202.15 & $1.433 \pm 0.02$ & $0.900 \pm 0.03$ \\
$\begin{array}{l}\text { Ethanol } \\
\text { extract } \\
\text { Experimental }\end{array}$ & 30.30 & 205.00 & 174.95 & 1.451 & 0.900 \\
$\begin{array}{l}\text { Ethanol } \\
\text { extract } \\
\text { literature }\end{array}$ & $27.55 \pm 0.55$ & $206 \pm 13.8$ & $178.45 \pm 13.25$ & $1.444 \pm 0.01$ & 0.903 \\
\hline
\end{tabular}

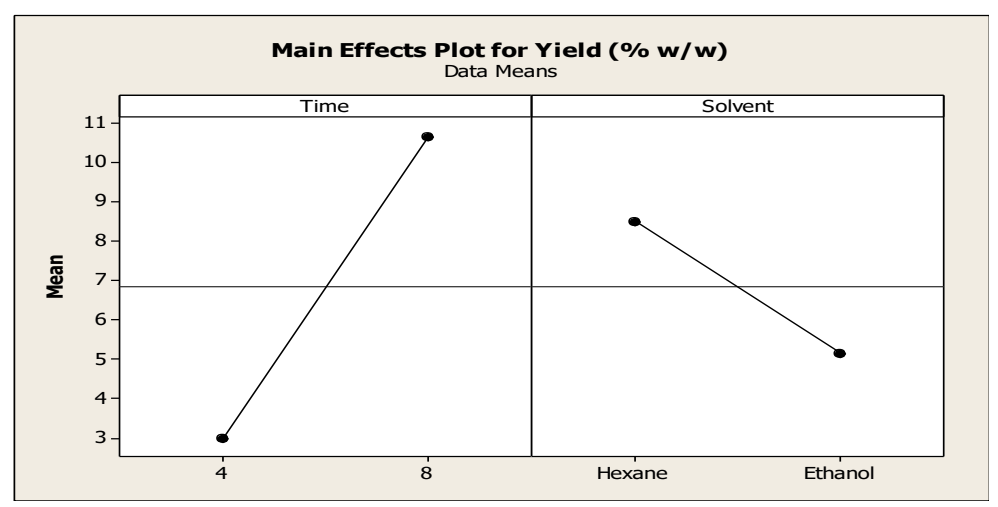

Figure 2:Main effects plot for mango oil yield 


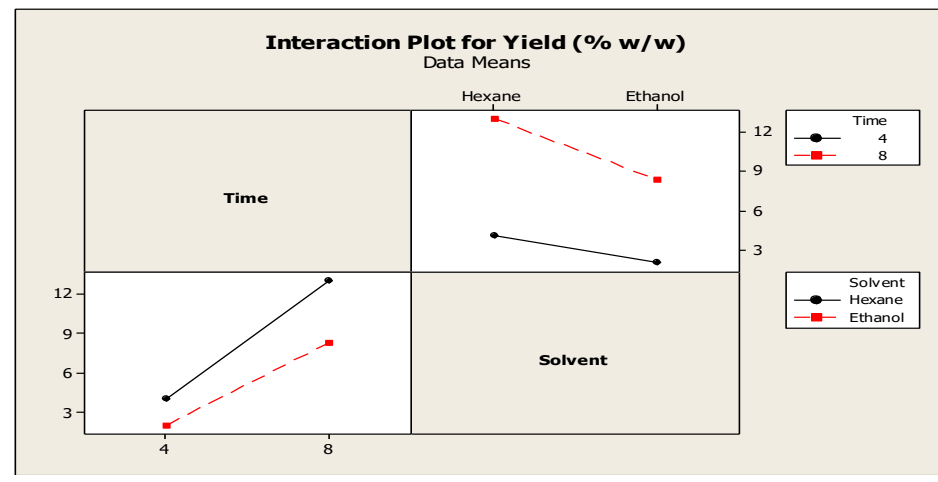

Figure 3:Full interaction plot matrix for mango oil yield

\section{DISCUSSION}

\section{The Effects of the Extraction Solvent and} Time on the oil Yield

The effect of extraction time on the yield is clearly shown in Table 1 and 2 using hexane and ethanol as extraction solvents, respectively. It was observed that the yield of oil increased as the time of extraction increases from 2 to 8 hours. This was so because enough time is required for the oil to break away from the kernel powder. The longer the time of extraction, the longer the kernel powder stays in contact with the extraction solvent. The rate of increase in yield is much faster at lower extraction times than at higher extraction times. This is so because as the time of extraction increases, the amount of oil that can be extracted from the kernel powder reduces until no more oil can be extracted.

Comparing the yields from the two solvents,results showed that hexane achieved more yield than ethanol at the different extraction times. This is because hexane is a very non-polar solvent which easily extracts the non-polar mango oil; while Ethanol which has both polar and non-polar parts doesn't extract as much oil. A polar solvent dissolves polar solutes easily and doesn't mix with non-polar solutes well. Thus ethanol can only dissolve oil because it has a non-polar part. In all, hexane is still considered as a better extraction solvent because it has a lower boiling point $\left(68^{\circ} \mathrm{C}\right)$ than ethanol $\left(78^{\circ} \mathrm{C}\right)$. This implies that hexane needs lesser energy than ethanol to extract. Apart, hexane is easier to recover after the extraction. Since ethanol requires a higher temperature than hexane, suffice to note that higher temperature might damage the oil being extracted.

The Factorial Experiment Design for the effects of various factors on the oil yield

In determining the oil yield, a factorial experiment was designed using 4 runs (i.e. $2^{2}$ ) where the 2 main effects are: $(\mathrm{A}=$ time $)$ and $(\mathrm{B}=$ extraction solvent $)$ was put into consideration at their highest and lowest values. (I.e. time $-=4$ hours and $+=8$ hours, extraction solvent $-=$ Ethanol and $+=$ Hexane). The absolute value of effect - main effects and interaction effects were determined and the result as presented in Table 3 shows that the factor A, time, as determined was the major factor affecting the oil yield with absolute value of 7.665. Thus, increase in time produces an increase in the yield of mango oil and also the factor B, extraction solvent, had a great effect on the oil yield with absolute effect of 3.335. The manual calculation of the factorial experimental results was compared with the factorial experimental design calculation using a software called "Minitab," as shown in Tables 4 and 5 and the results were found to compare favourably well and the same, particularly with extraction carried out with hexane. 


\section{Physicochemical properties of mango oil}

The acid value of mango oil is the mass of $\mathrm{KOH}$ in milligrams that is required to neutralize $1 \mathrm{~g}$ of the mango oil. Basically, the acid value is used to quantify the amount of acid (free fatty acids, acid phosphates or amino acids) present in a sample. For oils, it is a measure of the free fatty acid content. Free fatty acids exist in oil because of the hydrolysis of fatty acid which is usually accelerated with heat and pressure. Result shown in Table 6 revealed that the Ethanol extract has a higher acid than the Hexane extracted oil. This is because more fatty acids hydrolyzed during the ethanol extraction than during the hexane extraction. Since the hydrolysis is accelerated by heat, the ethanol extraction which requires a higher temperature than that of hexane would cause more fatty acids to hydrolyze. Hence, using ethanol as an extraction solvent yields an oil with high acid content. The acid value of both extracts agrees well with literature (Nzikwoet al 2010; Kittiphoom and Substasinee, 2013).

Refractive index is the ratio of the speed of light in a vacuum to that in the oil under examination which is related to the degree of saturation and the ratio of cis/trans double bonds. It can also provide hints on the oxidative damage andfor rapid sorting of fats and oils of suspected adulteration. The refractive index as shown in Table 6 increased from 1.443 to 1.451 for the hexane and ethanol extracts, respectively. it can be inferred that the refractive index of the ethanol extract was slightly higher than the hexane extract because the mango oil underwent adulteration due increase in heating temperature since the high boiling point of ethanol is higher $\left(78^{0} \mathrm{C}\right)$. However, both refractive index values of the mango oil compared well with literature (Nzikwoet al 2010; Kittiphoom and Substasinee, 2013).

The differential analyses of the saponification value of the two extracts were found to be of a negligible amount. It implies that the saponification value of mango oil is not dependent on the extraction solvent used. This high saponification value of the extracted oil makes a good candidate for the soap industry. Both saponification values of the mango oil fall within the literature range of values (Nzikwoet al 2010; Kittiphoom and Substasinee, 2013).

Suffice to note that the ester values decreased from 201.39 to 174.95 for the hexane and ethanol extracts, respectively, andthe higher the ester value, the more the palatability of the oil. Hence the hexane extracts would be more palatable. Both ester values and together with the specific gravity of both hexane and ethanol extracts were also found to fall within literature range (Nzikwoet al 2010; Kittiphoom and Substasinee, 2013).

\section{CONCLUSION}

The use of soxhlet extractor for the extraction of oil from mango seed was found to dependmajorly on two factors; extraction solvent and time of extraction. Although the time factor was the major determinant of the mango oil yield, however, the use of hexane gave a higher yield than ethanol.The acid value and refractive index of the mango oil from ethanol extraction were higher than those of the hexane extraction. The ester value from the hexane extract was also higher than that of the ethanol extract.Thus, this study has shown that hexane extraction gives a higher oil yield and better quality than ethanol extraction.

NWAOKOBIA, K. Department of Agricultural and Bio-Environmental Engineering Technology, Federal Polytechnic; IDIBIE, C.A, Department of Chemical Sciences, Edwin Clark University; OGBORUR.O., Research Coordinating Unit, Forestry Research Institute of Nigeria; and OKOLIE, P.L., Department of Chemistry, Delta State University, Abraka, Nigeria.

\section{REFERENCES}

A.O.A.C., 1998. Official methods of analyses. Washinton, DC: Association of Official Analytical Chemist

Bird, S. R. (2013). A Healing Grove: African Tree Remedies and Tituals for the Body and Spirit. Chicago Review Press. 
DEV SANSKRITI: Interdisciplinary International Journal (2018), 12, 43-51

Fahimdanesh, M., \& Bahrami, M. E. (2013). Evaluation of

Physicochemical Properties of Iranian Mango Seed. International Food Research Journal. IPCBEE vol.53 (2013) (C) (2013) IACSIT Press,

Singapore.

Kittiphoom, S. (2012). Utilization of Mango seed. International Food

Research Journal 19(4): 1325-1335

Kittiphoom, S., \& Sutasinee, S. (2013). Mango Seed Kernel Oil and its

Physicochemical Properties. International Food Research Journal

20(3): 1145-1149

Nzikuo, M. T., \& Pizzorno, J. E. (2010). The Encyclopedia of Healing

Foods. Simon and Schuster.

Nielsen, S. S. (2010). Food Analysis. Springer Science and Business

Media.

Nigam (2007). Lab Manual in Biochemistry: Immunology and

Biotechnology. McGraw Hill Education, New York

O'Brien, R. D. (2008). Fats and oils: Formulating and processing for applications. (3rd, Ed.) CRC press.

Pomeranz, Y., \& Meloan, C. E. (2002). Food Analysis: Theory and

Practice. Springer Science and Business Media.

Preedy, V. R., Vatson, R. R., \& Patel, V. B. (2011). Nuts and Seeds in Health and Disease Prevention. Academic Press.

Singh, L.B (1960). The Mango( Botany, Cultivation and Utilization). Leonard Hill, London, U.K

Sivkishen. (2014). Kingdom of Shiva. Partridge India.

Sondhi, A. (2011). Wonders of India Trees. TERI press.

Williams, J. (2007). The origin of Soxhlex apparatus. Journal of Chemistry Education 84(12):1913-1918 